\title{
Evaluation of the Probiotic Mixture and Bacitracin Methylene Disalicylate Supplementation on Intestinal Health of Clostridium perfringens Induced Necrotic Enteritis in Broiler Chickens
}

\author{
S. Rathnapraba* \\ Department of Animal Biotechnology, Madras Veterinary College, TANUVAS, Chennai, India \\ *Corresponding author
}

\section{A B S T R A C T}

Keywords

Necrotic enteritis, Broilers chickens, GalliproTect ${ }^{\circledR}$, TLRs and cytokines

Article Info

Accepted:

12 January 2021

Available Online:

10 February 2021
An experiment was carried out to investigate the efficacy of probiotic GalliproTect ${ }^{\circledR}$ and bacitracin methylene disalicylate (BMD) on improving intestinal health against $C$.perfringens induced necrotic enteritis (NE) in broilers. Five hundred 500 day-old broiler chicks (Cobb 400) were divided into five treatment groups, each with five replicates of 20 chicks each by following a completely randomized design. The treatments were an uninfected control (T1), an infected control (T2), an infected group supplemented with probiotic GalliproTect ${ }^{\circledR}$ at $500 \mathrm{~g} /$ tone of feed (T3), containing $2 \times 10^{10} \mathrm{cfu} / \mathrm{g}$, an infected group supplemented with BMD at $500 \mathrm{~g} /$ tone of feed (T4) and an infected group supplemented with probiotic + BMD each at $500 \mathrm{~g} /$ tone of feed (T5). Necrotic enteritis was induced in the broilers by oral inoculation of 30,000 sporulated Eimeria necatrix oocysts on day 14 followed by Clostridium perfringens inoculation $1.0 \mathrm{~mL}\left(10^{8} \mathrm{cfu} / \mathrm{mL}\right)$ on day 19 to 21 in group T3, T4 and T5.On day 28 ( $7^{\text {th }}$ day post infection) scoring of gross lesions were performed. Illeal mucosal samples were collected for mRNA quantification of TLR and cytokine gene by real time PCR. Histological scores revealed that intestinal necrotic lesions and inflammatory changes were reduced. Toll like receptors (TLRs) and cytokine gene expression revealed that probiotic group found to increase interleukins levels and decrease TLR 2 levels in necrotic enteritis infected chickens. Thus, the results suggested that the probiotic supplementation could able to regulate the intestinal mucosal immune response and there by ameliorate inflammation by altering the cytokine and TLR gene expression.

\section{Introduction}

Necrotic enteritis caused by Clostridium perfringens is one of the most important bacterial diseases of poultry which is sporadic in nature and has been reported from most parts of the world (Timbermont et al., 2011). This disease usually occurs in broiler chickens of 2-6 weeks and in layers of 12-24 weeks of age. The disease occurs when high numbers of bacteria coincide with a damaged intestinal mucosa. Clostridium perfringens produces many minor toxins and the most important are $\beta 2$ and enterotoxin (Van Immerseel et al., 2004).Necrotic enteritis in poultry could be controlled by supplementation of infeed antibiotic growth promoters (AGPs) and ionophores 
compounds. However, the usage of antibiotics in broilers is banned in most of the countries, it is necessary to find an alternative for this problem to improve the gut health of the broilers. Several probiotic bacterial strains have been shown to prevent or reduce the incidence of diseases caused by pathogenic bacteria (Chaucheyras-Durand and Durand, 2010).One such alternative could be increasing the balance of healthy bacteria to protect the gut from colonization of pathogenic bacteria. Several probiotics species have been used as additive in poultry feed to protect chicken against enteric pathogens (Higgins et al., 2008). Although there are scientific evidences supporting the anti - inflammatory property of probiotic GalliproTect $^{\circledR}$, only few studies have been conducted in evaluating their protective immune response against necrotic enteritis in chicken. Hence, the present study was undertaken to find the effectiveness of probiotic GalliproTect ${ }^{\circledR}$ over Bacitracin methylene disalicylate (BMD) in controlling necrotic enteritis in commercial broiler chicken.

\section{Materials and Methods}

\section{Bacterial strains and culture condition}

Clostridium perfringens (MTCC No. 450) procured from MTCC Chandigarh was cultured under anaerobic condition in reinforced Clostridial broth to prepare cells for the experimental infection model. The bacteria were harvested via centrifugation at $6,000 \times \mathrm{g}$ for $10 \mathrm{~min}$ at $4^{\circ} \mathrm{C}$ and resuspended in $0.01 \mathrm{M}$ PBS to the desired concentration before use. The concentration of bacterial cells was adjusted to $10^{8} \mathrm{cfu} / \mathrm{mL}$, with optical density determined as 0.8 at an absorbance of $600 \mathrm{~nm}$.The probiotic GalliproTect ${ }^{\circledR}$ and BMD procured from Evonik Pvt Ltd., SEA, Singapore was used in the study.

\section{Experimental design}

A total of 500 day-old broiler chicks were individually weighed, wing banded and randomly allocated into five treatments each with five replicates of 20 birds each. The treatments were Non challenge control group (T1), Clostridium perfringens challenge group (T2), C. Perfringens challenged + GalliproTect ${ }^{\circledR}$ group (T3), C. perfringens challenged+ BMD group (T4) and $C$. perfringens challenged + GalliproTect $^{\circledR}+$ BMD group (T5). The GalliproTect ${ }^{\circledR}$ probiotic mixture contains Streptococcus feacalis $\left(2 \times 10^{10}\right)$, Bacillus mesentericus $\left(2 \times 10^{8}\right)$, Clostridium butyricum $\left(2 \times 10^{9}\right)$, Yucca extract $10 \%$. The birds were fed with pre starter (0-7 day), starter (8-21 day) and finisher (22-42 day). Coccidial inoculation was carried out with 30,000 sporulated Eimeria necatrix oocysts on day 14 followed by challenged with Clostridium perfringens (MTCC No. 450, MTCC, Chandigarh) inoculation $1.0 \mathrm{~mL}$ $\left(10^{8} \mathrm{cfu} / \mathrm{mL}\right)$ on day 19 to 21 in treatment group $\mathrm{T} 2, \mathrm{~T} 3$ and $\mathrm{T} 4$.

The group T1 was kept as control and fed with diet supplemented with coccidiostat. Standard managemental practices were followed. The birds were fed ad libitum with experimental diet and provided with clean, fresh potable water throughout the experimental period. The experimental diets were formulated and prepared according to BIS (2007) standard in mash form. The chemical composition of the experimental rations was analyzed as per the procedure of AOAC (2005). Whereas the calcium, available, lysine, methionine plus cystine and metabolizable energy content were calculated from the composition of the feed ingredients, according to BIS 2007. The birds were monitored for clinical signs of haemorrhagic enteritis, inappetence, leg weakness, nervous signs (paralysis of legs) during experimental periods. Two numbers of birds (male and 
female one each) from each replicate of the treatment groups was sacrificed by cervical dislocation for the intestinal lesion scoring studies on day 28 (7-day post infection) of the trial. The intestinal segments were removed and gently flushed with $0.9 \% \mathrm{NaCl}$ to remove the intestinal contents. Illeal mucosal samples of 24 birds, 6 from each experimental group were collected to analyse cytokine and TLR gene expression studies.

\section{Macroscopic and Histological Examination}

Birds were monitored for any clinical sign or symptom of necrotic enteritis such as huddling, diarrhoea,leg weakness, depression or mortality during the experimental period. All birds that died during the course of the experiments were necropsied to determine the cause of death.

\section{RNA isolation and real time PCR for cytokine and TLR genes}

On day 28 day, six birds from each treatment group were euthanized by cervical dislocation and a section of the ileumwere sampled, rinsed in cold PBS, placed in RNAlater (Qiagen) and stored at $-80^{\circ} \mathrm{C}$ for subsequent gene expression analysis.Total RNA was extracted from individual samples using the RNeasy mini kit following the animal tissue protocol (Qiagen).

The expression of the gene of interest was estimated from six birds per treatment and run in duplicate per sample. Primers used in this study were given in the (Table 1). Average gene expression relative to the endogenous control for each sample was calculated using the 2- $\Delta \Delta \mathrm{Ct}$ method (Livak and Schmittgen, 2001). The calibrator for each gene was the average $\Delta \mathrm{Ct}$ value from the negative control group for each sampling day for each respective tissue.
Gene expression fold change, Standard error and statistical significance were calculated based on the formula developed by Pfaffl's (2001).

\section{Results and Discussion}

\section{Gross pathology and histological examination}

On clinical observation, high percentage of (70\%) the clinicalsymptoms of necrotic enteritis in challenged group, $10 \%$ in (challenged + BHD) group, 4\% and least in (challenged+GalliproTect ${ }^{\circledR}+$ BHD). Result indicated that higher incidence of necrotic enteritis was observed in challenge group where as low percent was observed in disease challenged birds fed on GalliproTect ${ }^{\circledR}$ supplemented diet andalso in challenged birds supplemented with both GalliproTect ${ }^{\circledR}$ and BMD.

Similarly, high incidence of fatty liver syndrome, nervous condition and leg weakness was observed in challenge group when compared to all other groups. There was no pathological changes in the intestinal tissue of the non - challenge control group. In contrast, birds in C.perfringens challenge group exhibited hyperaemia of intestinal lumen. Severe necrotic lesions were observed in intestinal mucosa.

Histopathology of the control group revealed intact mucosa and C.perfringens challenge group exhibited strong intestinal damage, neurotropic infiltration into lamina propria and hyperplasia of lamina propria whereas the challenged groups supplemented with either probiotics (T3) or with BMD (T4) the lesions were reduced.These findings are supported by the previous results suggesting that probiotics had potential role in preventing enteric diseases (Panda et al., 2008). 
Table.1 Primers used for relative real-time PCR

\begin{tabular}{|c|c|c|c|}
\hline Target & Nucleotide sequence $\left(5^{\prime} \rightarrow 3^{\prime}\right)$ & $\begin{array}{l}\text { Product } \\
\text { size (bp) }\end{array}$ & $\begin{array}{c}\text { Annealing } \\
\text { Temperature } \\
\left({ }^{\circ} \mathrm{C}\right)\end{array}$ \\
\hline TLR2 F & AGGCACTTGAGATGGAGCAC & \multirow[t]{2}{*}{314} & \multirow[t]{2}{*}{56} \\
\hline TLR2 R & CCTGTTATGGGCCAGGTTTA & & \\
\hline TLR4 F & GTCTCTCCTTCCTTACCTGCTGTTC & \multirow[t]{2}{*}{187} & \multirow[t]{2}{*}{56} \\
\hline TLR4 R & AGGAGGAGAAAGACAGGGTAGGTG & & \\
\hline IL-8 F & ATGAACGGCAAGCTTGGAGCTG & \multirow[t]{2}{*}{233} & \multirow[t]{2}{*}{57} \\
\hline IL-8 R & TCCAAGCACACCТСТСТTCСАТCC & & \\
\hline B Actin F & CAACACAGTGCTGTCTGGTGG & \multirow[t]{2}{*}{205} & \multirow[t]{2}{*}{55} \\
\hline B Actin R & ATCGTACTCCTGCTTGCTGAT & & \\
\hline
\end{tabular}

Fig.1 Gene expression profile of TLR 2

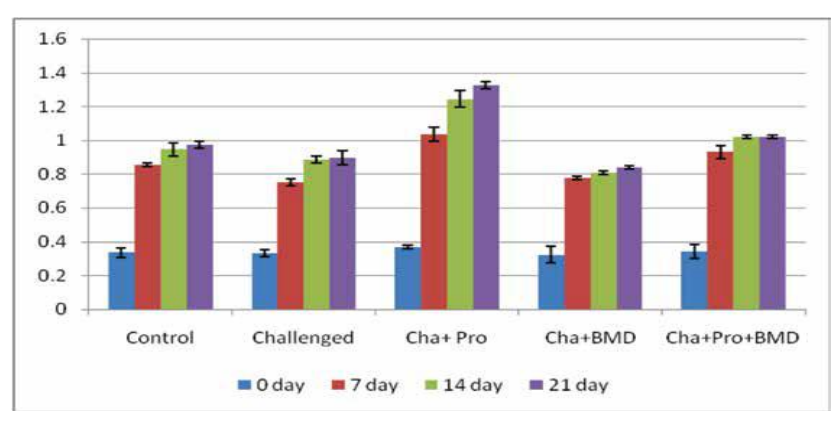

Quantification of mRNA expression level of cytokine and TLR genes

On gene expression studies, there was no significant difference on TLR-2 gene expression observed between the groups on 0th day (Figure 1). Whereas in case of $7^{\text {th }}$, $14^{\text {th }}$, and $21^{\text {st }}$ day TLR-2 gene expression was upregulated in necrotic enteritis challenged birds received on GalliproTect ${ }^{\circledR}$ supplemented diet (T3). There was no significant difference observed in challengedbirds fed on diet supplemented with GalliproTect ${ }^{\circledR}+$ BMD (T5) when compared to control group. On the other hand, TLR -2 gene expression was decreased in challenged and also in challenged $+\mathrm{BMD}$ group when compared with control group.TLR -4 expression was decreased in all the groups when compared to control group on 0th day. Whereas, in case of $7^{\text {th }}$, $14^{\text {th }}$ and $21^{\text {st }}$ day TLR -4 gene expression was upregulated in challenged + GalliproTect ${ }^{\circledR}$ group but the TLR-4 level was decreased in challenged, challenged + BMD and challenged + GalliproTect ${ }^{\circledR}+$ BMD group compared to control group. However, there was no significant difference observed between challenged birds fed on GalliproTect ${ }^{\circledR}+$ BMD supplemented diet and control group on $7^{\text {th }}$ day of age.The upregulation of TLR-4 gene in challenged + GalliproTect ${ }^{\circledR}$ group may be due to probiotic mediated innate immune response.Similar results were also observed in TLR-4 gene expression. Upregulation of these genes in challenged + GalliproTect $\AA$ may due to the immunomodulatory effects of probiotic supplementation. TLRs, as a type of pattern recognition receptor, can activate immune responses and regulate inflammatory responses. In the previous study, Cario and Podolsky, 2000 reported that oral 
administration of probiotics caused an increase in Tlr3 and Tlr4 gene expressions and their results showed that after dietary administration of $B$. subtilis increased the mRNA expression level of Tlr4.

To evaluate the effects of the adaptive immune response, the IFN $\gamma$ and IL8 cytokines that play vital role in regulating the innate immune responses were analyzed. Expression of the genes IFN $\gamma$ and IL8 were downregulated both in Challenged + GalliproTect ${ }^{\circledR}$ group and Challenged + BMD+ GalliproTect ${ }^{\circledR}$ treated group on days 7 and 14 when compared to the challenge group. The above result of reduced the gene expression may be due to reduction in the intestinalcolonization by pathogenic bacteria due to competitive exclusion by probiotic bacteria. Probiotics can help animals resist pathogenic bacteria infections. The epithelial cells of the intestinal mucosa are crucial in coordinating the defence mechanisms after pathogen infection by recruiting immune cells (Schauser et al., 2005) and act on the epithelial cells, thereby stimulating the release of cytokines.

From the results of the present study it can be concluded that the supplementation of GalliproTect ${ }^{\circledR}$ at the rate of $500 \mathrm{~g} / \mathrm{MT}$ not only controlled $C$. perfringensinduced necrotic enteritis in broilersbut also modulate intestinal mucosal immune response by upregulation ofTLR-2 gene expression in challenged and GalliproTect ${ }^{\circledR}$ group from $7^{\text {th }}$ day onwards indicating better immune response due to probiotic supplementation. Hence, GalliproTect ${ }^{\circledR}$ can be used as analternative for antimicrobial growth promoters in controlling necrotic enteritis in broilers.

\section{Acknowledgement}

The authorgreatly acknowledges the M/s
Evonik (SEA) Pvt.Ltd, Singapore-609 927 for their financial support and TANUVAS to carry out this research work through Industry University Collaborative Research Project.

\section{Conflict of interest}

The author expresses no conflict of interest with regard to the information mentioned in this research article.

\section{References}

AOAC, Official Methods of Analysis. (18th ed.). Ed. Horwitz, W., Association of Analytical Chemists, AOAC International, Arlington Virginia, USA, 2005.

BIS. 2007. Bureau of Indian Standards of poultry feed. Manak Bhawan, 9, Bahadur Shah Zafar Marg, New Delhi, India.

Cario, E and Podolsky, D. K. 2000. Differential alteration in intestinal epithelial cell expression of toll-like receptor 3 (TLR3) and TLR4 in inflammatory bowel disease. Infection and Immunity. 68: 7010-7017.

Chaucheyras Durand, Fand Durand. H.2010.Probiotics in animal nutrition and health.Beneficial microbes.1(1):3-9.

Higgins, S. E., J. P. Higgins, A. D. Wolfenden, S. N. Henderson, A.TorresRodriguez, G. Tellez and Hargis,B. 2008. Evaluation of a Lactobacillusbased probiotic culture for the reduction of Salmonella enteritidis in neonatal broiler chicks. Poultry Science. 87:2731.

Livak, K.J and Schmittgen. T. D.2001. Analysis of relative gene expression data using real-time quantitative PCR and the 2(-Delta Delta C(T)) method.Methods. 25(4):402-408

Panda, A. K., S. S. R. Rao, M. V. Raju and Sharma. S. S. 2008. Effect of probiotic 
(Lactobacillus sporogenes) feeding on egg production and quality, yolk cholesterol and humoral immune response of White Leghorn layer breeders. Journal of the Scienceof Food and Agriculture. 88:43-47.

Pfaffl, M.W. (2001). A new mathematical model for relative quantification in realtime RT-PCR. Nucleic Acids Res. May 1; 29(9): 45

Schauser, K., J.E. Olsen and Larsson. L.I. 2005. Salmonella typhimurium infection in the porcine intestine: Evidence for caspase-3-dependent and independent programmed cell
death.Histochem. Cell Biology. 123: 4345.

Timbermont, L.,F. Haesebrouck, R. Ducatelle and Immerseel, F.V. 2011. Necrotic enteritis in broilers: an updated review on the pathogenesis. Avian Pathoogy. 40(4): 341-347.

Van Immerseel, F., J. De Buck, F. Pasmans, G. Huyghebaert, F.Haesebrouck and Ducatelle. R. 2004. Clostridium perfringens in poultry: An emerging threat for animal and public health. Avian Pathology. 33:537-549.

\section{How to cite this article:}

Rathnapraba, S. 2021. Evaluation of the Probiotic Mixture and Bacitracin Methylene Disalicylate Supplementation on Intestinal Health of Clostridium Perfringens Induced Necrotic Enteritis in Broiler Chickens. Int.J.Curr.Microbiol.App.Sci. 10(02): 265-270.

doi: https://doi.org/10.20546/ijcmas.2021.1002.032 